\title{
Social satire on higher education: A comparative structural semiotic study of the movies Alangkah Lucunya (Negeri Ini) and Parasite
}

\author{
Yulianeta $^{1}$ and Rosmah Tami ${ }^{2}$ \\ ${ }^{I}$ Department of Indonesian Language and Literature Education, Faculty of Language and Literature Education, \\ Universitas Pendidikan Indonesia, Jl. Dr. Setiabudhi No. 229, Bandung, West Java, Indonesia \\ ${ }^{2}$ Department of English Language and Literature, Faculty of Adab and Humaniora, UIN Alauddin Makassar \\ Jl. H.M. Hasim Limpo No. 36 Samata Gowa, Indonesia
}

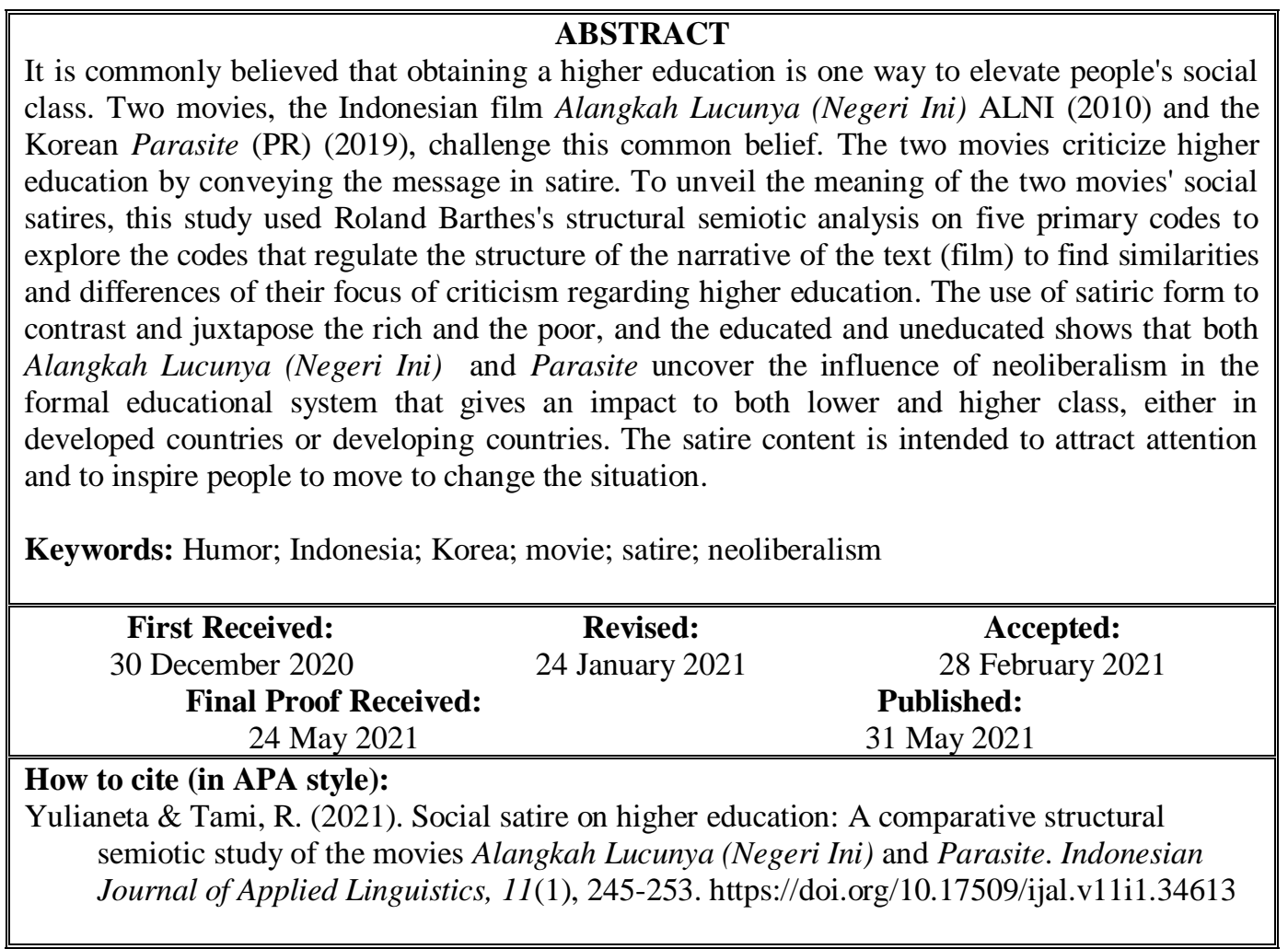

\section{INTRODUCTION}

Amidst the belief of higher education as a key to victory, several films appear to mock the product of higher education humorously. Since the 2010s, several films around the world have notably captured the problem faced by the world of education such as Alangkah Lucunya Negeri Ini (ALNI) (2010), Ivory Tower (2014), Bad Genius (2017), and Parasite (2019). The issues such as the skyrocketing tuition fee, cheating, bribery, and corruption are depicted satirically and consumed comically by a large global popular culture's audience. In humor, people take amusement in the ignorance of other people as moral criticism. Thus, when educated people and the educational system become the object of humor in popular culture, some provoking issues regarding morality—which has been prolonged as the essence and aim of people pursuing education - should be examined.

Similar to the movie's illustration, the morality of educated people is also massively reported and discussed globally either in popular newspapers or in scholarly work. Many newspapers pay attention to the educational degree held by corruptors amid corruption cases in Indonesia and directly questions the function of higher education as a place to harvest knowledge and wisdom (Kompas, 2019; Media Indonesia, 2019; Okezone, 2019; Republika Online, 2020; Wartakota, 2019). In academic research, Giroux (2004) relates the decadence of morality in

\footnotetext{
*Corresponding Author

Email: yaneta@upi.edu
} 
education to neoliberalism as public education becomes the target of neoliberalism. Neoliberalism in higher education is also found by Byean (2015), who tracks the ideology of neoliberalism in English teaching in South Korea. In Indonesia, neoliberalism impacts the increase in tuition fees and the low quality of education in higher education (Rachman, 2017). This condition leads to the commercialization of higher education (Wahyudi, 2015) and affects students' psychology in both countries (Abelmann et al., 2009; Sutanto, 2016).

As a fundamental critical entertainment with their intention and aspiration, two satiric films from two countries, Parasite (2019), which depicts the struggle of a lower-class Korean family living in a semi-basement apartment, and Alangkah Lucunya (Negeri Ini) (ALNI) (2010), which portrays the struggle of university alumnae, are the focus of this article. As satiric movies, they are considered to be part of comedy, and comedy is viewed as lower art compared to tragedy. Comedy is not commonly considered to be as potent a form of critical intervention. Nevertheless, according to McClennen (2011, p. 3), satire is not meant to merely entertain and amuse its audience but it aims to attract attention to think critically. Furthermore, McClennen and Maisel (2014) show that the goal of satire is to expose human folly and to inspire critical thinking and reason in social engagement. Satire does not make people laugh at something, but make people laugh at their own stupidity. Even though almost all satire use irony, satire itself is not an irony. The irony is all about the opposites; meanwhile, satire is just a form of derision in the face of foolishness. It also differs from mockery, cynicism, and sarcasm, though these may be seen in satire. Satire always has a clear goal to promote critical thinking; meanwhile, mockery only conveys its messages. It is fundamentally different in their intention and inspiration.

Many researchers have studied ALNI, such as Anwar (2019) who found the social inequalities in the film, Susanti and Asyari (2017) on moral teaching, and Hasanah et al. (2017) on character building. However, these studies do not give specific attention to the form of satire contained in the film. Another study using semiotic analysis on the movie conducted by Sudarso et al. (2015) tries to unveil the mythological meaning using Barthes' theory. Nevertheless, this study still does not give much attention to the satire in the movie and only focuses on the mythological meaning. Likewise, film reviewers such as Peter Bradshaw (2020), from The Guardian and David Sims (2019), from The Atlantic, unveil that Parasite represents social inequalities. They neglected the tone of education, even though the dialogue and symbols regarding education significantly moves the two movies' structures.
This article argues that the two films satirically criticize similar fundamental problems regarding higher education. However, satire does not usually express its idea directly, instead of its opposites. Therefore, to find the fundamental meaning of their intention and aspiration, the movies' structures are examined using a semiotic structural narrative. To find the implicit meaning of the two movies' intention and inspiration, this article employs two critical questions; (1) what is the meaning of education narrated in the two movies based on Barthes' five codes (2) why does satiric code regulate these film narratives? The structural semiotic employed here is developed by Roland Barthes. This theory examines five principal codes that rule the structure of films' narratives (Allen, 2003).

\section{METHOD}

The comparative structural narrative is used to compare the structure of the two films' intention and inspiration. The comparative study does not intend to show the similarities, but this study departs from similarities of the films to find their differences (Faruk, 2018, p. 90). The formal object is the structural narrative of education, while the material object is two satiric movies, Alangkah Lucunya Negeri Ini (ALNI), directed by Deddy Miswar, and Parasite, directed by Bong Joon Ho. Parasite criticizes the exceedingly high cost of education fee, which is unaffordable for the poor and leaves them in the lowest social location. ALNI tells about a jobless university alumna named Muluk who meets a pickpocket named Comet that unexpectedly opens up job opportunities for Muluk. Together with the pickpockets, Muluk got a place to apply his knowledge.

Movie is one of the signs which consist of signifiers and the signified. The signifiers in movies are structurally combined syntagmatically and selected paradigmatically in order to form meaning. In the movie, the paradigms consist of ways of changing shots such as cut, fade, dissolve, and wipe. The choice of satire as a genre or medium is also a paradigm. Semiotician believes this structure is constructed and not neutral because the choice involves inclusion and seclusion. A syntagm is an orderly combination of interacting signifiers which forms a meaningful whole within a text (Chandler, 2007, p. 147)

Code governs the rule in combining and selecting the structure to affect the texture of the structure (Johansen \& Larsen, 2004, p. 7). Signs in a movie manifest in pictures, sounds, and dialogues to signify its reference so that its audience can receive its messages. The combination or selection of signifiers to structure and represent a more prominent structure, namely narrative, appeared in the texture or genre of a story (McQuillan, 2002, p. 
109). Barthes (1977, p. 79) points out that a structural narrative analysis explores the story or narrative of a bigger structure such as a movie. For Barthes, narrative is a collection of events, and this event produces a particular type of genre; here, the genre is identified as satire.

Besides, it is impossible to combine and produce a narrative without a reference to an implicit system of units and rules. The unite here is the structure, and the rule is the code. Code can be in many forms such as cultural code, social code, language code, etc. In his theory, Barthes proposes five codes to identify the meaning of the narrative, namely hermeneutic, semantic, proairetic, cultural, and symbolic codes. Hermeneutic code refers to any element in the story that is not explained. It refers to all the enigmatic, puzzling, and mysterious elements of a text that make the reader curious to unveil their mystery. Next, the proairetic code means a major structure that builds interest or suspense for the audience. This code creates tension in the plot that plays dual roles; first, they proclaim that something is going to happen, and second, they make the audience attentive and respondent to resolve the tension. The third code is semantic code that refers to any narrative element that suggests a particular meaning by connotation or associated meaning. This code is also called connotative meaning by which a text can better be understood by implying its connotative meanings. This code helps the reader to understand the theme of the texts. The fourth code is symbolic. This code can be understood by thinking of the symbolic code as a more profound structural principle that organized semantic meanings through mediations and antitheses or contradictions in the narrative structure. This code is also known as antithetical code. The fifth code is the cultural code or referred code. Cultural code composes any units in a narrative that refers to a science or a body of knowledge. Here, the reader focuses on the physical, physiological, medical, psychological, literary, and historical properties of characters of the story to identify a common knowledge (Barthes, 2002, pp. 18-20).

These five codes help to understand the thematic meanings of the story. By applying these codes to the narrative of the two movies, a reader can transform the simple text into a writerly text. A writerly text is a sort of modern text in which the reader has full freedom to produce multiple textual meanings. Meanwhile, a readerly text is a traditional text in which the reader's main objective is to accept all that is already written passively. The grouping of codes forms a braid (text, fabric, braid); each thread, each code, is a voice; these braided voices form the writing from which the satire tone can be interpreted (Barthes, 1977).

After finding the codes regulating the two films' structures, they are further compared to find the similarities and differences between the two countries in the way they structure their criticism satirically through the films. This part is discussed in the last part of this article.

\section{FINDINGS \\ The Narrative Structure of Satire in Alangkah Lucunya (Negeri Ini) \\ The hermeneutic code}

To find the fundamental meaning of the intention and inspiration of the movies, the first to be identified is the hermeneutic code. Under the hermeneutic code, various forms of an enigma can be distinguished, suspected, formulated, defended, and finally unveiled. This code can be read in several events in scenes from both movies as shown in the Table 1.

\section{Table 1}

\begin{tabular}{ll} 
Hermeneutic Code & Parasite \\
\hline ALNI & The title of the movie \\
\hline $\begin{array}{l}\text { The title of the movie } \\
\text { A job seeker applying for a } \\
\text { job }\end{array}$ & $\begin{array}{c}\text { The scene of semi } \\
\text { ground apartment and } \\
\text { upper hill house }\end{array}$ \\
$\begin{array}{l}\text { A proud pickpocket in a } \\
\text { busy crowded densely } \\
\text { populated city }\end{array}$ & $\begin{array}{l}\text { A poor family's struggle } \\
\text { for phone signal to } \\
\text { check job order. }\end{array}$ \\
$\begin{array}{l}\text { Heated conversation on } \\
\text { higher education in a } \\
\text { mosque }\end{array}$ & $\begin{array}{c}\text { The busy life of a rich } \\
\text { family preparing a } \\
\text { private tutor for kids }\end{array}$ \\
\end{tabular}

As it is shown in the Table 1, the hermeneutic code seen from ALNI is the title of the movie. It follows by the scene of a figure passing crowds from one bankrupt office to another to apply for a job. The job seeker is an already two-year university alumna, but his university diploma seems to be rejected and useless because companies are facing bankruptcy. Another enigmatic code is a pickpocket who is caught by Muluk. This scene introduces Muluk's education, morality, and ideal belief. Another scene shows a heated conversation between Pak Makbul, a humble tailor who has a strong belief in the bright future of educated people, and who has spent his money for his son's higher education, and Haji Sabirin, a modest trader who tries to convince Pak Makbul that higher education is useless.

The display of the useless university diploma of the unemployed university alumnae, illiterate pickpocket, and the contrasting views of education between Pak Makbul and Pak Sabirin formulate the following events combined and selected in the plot of the movie. These depictions can guide readers to question where the structure of the plot brings the reader. All those views seem to challenge the existing myth of education as social mobilization (Amin, 2016) by raising some paradoxical realities which raise the question regarding university alumnae. 
The movie Parasite depicts several enigmatic views. The first thing to be noticed is the portrayal of a semi-basement apartment downhill where a family lives along with the appearance of the title card, Parasite. The word Parasite is denotatively interpreted as an organism whose life is attached to other living things. After this scene, the film shows the busy life of a rich family who lives in a luxurious upper hill mansion. The locations of the two houses and the title card are enigmatic in how these codes relate to each other.

Both movies depict the life of lower-class society in the city. The Korean movie shows an apartment where people live individually, meanwhile the Indonesian movie illustrates a densely populated kampong where people know each other. The kampong has a mosque and a traditional security post where people gather, discuss their problems, pray or play. In contrast to the Korean movie, the lower-class family is isolated. Passerby drunkards do not even notice them to the point of urinating on their window. While ALNI portrays a larger populated area, both movies, however, discuss the difficulties of lower-class families in having a permanent and respectable job.

\section{The proairetic code}

This code is the narrative code by which readers focus on actions and specify their reactions. The action and reaction system raise interest in the reader. Proairetic is a direct narrative action that occurs in various sequences. It explains and narrates the enigmatic scene. This proairetic code can be found in several scenes as shown in the Table 2

Table 2

Proairetic Code

\begin{tabular}{lc}
\hline ALNI & Parasite \\
\hline The pickpocket offers & $\begin{array}{c}\text { The struggle of a poor } \\
\text { family to make ends } \\
\text { Muluk chicken curry }\end{array}$ \\
Kuluk finds a job & $\begin{array}{c}\text { Ki Woo's friends offer a } \\
\text { job as a tutor }\end{array}$ \\
$\begin{array}{c}\text { Muluk, Pipit, and Samsul } \\
\text { educate the pickpocket }\end{array}$ & $\begin{array}{c}\text { Woo to work for the } \\
\text { rich family }\end{array}$ \\
\hline
\end{tabular}

Proairetic code can be seen in the reaction of Muluk after knowing the pickpocket, Comet. When he is ordering a portion of cheap humble food for lunch from a small street food vendor, Comet, who is also in the same place and enjoying his lavish meal, offer a treat to Muluk a chicken curry meal. Muluk's pride as an educated man is destroyed. Several reactions follow this scene such as Muluk joins the pickpocket, Muluk convinces the pickpocket's boss to manage their money, and Muluk opens the pickpockets' eyes to bigger money through pursuing education. This scene further exposes the problem in education as depicted in the dialogue below:
The educated people steal money from a safety deposit box while pickpockets steal money from wallets. Educated people are called corruptors, while pickpockets are thieves. The educated corruptors steal far more money than do the pickpockets and are treated far better than the pickpockets.

This paradoxical argument dazes the pickpockets who never think of such a way to collect more money. Then the pickpockets' group begins to follow Muluk's instruction aim for bigger money through education. This intention for education to gain more money is a satirical scene to the current vision and mission of higher education in supporting students to pursue their education.

Similar to ALNI, the South Korean family also believes that education is very important for children's future. It is higher education that may help them pass the border to the life of a higherclass society. It is after $\mathrm{Ki}$ Woo fabricated a university diploma that he can enter the upper hill mansion. This diploma gives him some opportunity to seize income and lavish living in the upper hill house. Not only that, by holding a fake diploma of the best South Korean university, Ki Woo and his sister, Ki Jung are able to construct their imagined social class and present them to their upper-class family in order to be accepted, and to have an opportunity to live the life of luxury. The two movies agree that education can improve or maintain the level of the economic class of a family.

\section{Connotative code}

Connotative code explains the appearance of an element of the narration, which is attentively connotative. This code appears as a hint, guidance to signal and direct the reader to uncover the meaning. The table below shows some connotative codes identified from the two movies (see Table 3).

Table 3

\begin{tabular}{|c|c|}
\hline$A L N I$ & Parasite \\
\hline $\begin{array}{l}\text { Character's language, } \\
\text { Costumes, environment }\end{array}$ & $\begin{array}{l}\text { Character's language, } \\
\text { Costumes, environment }\end{array}$ \\
\hline $\begin{array}{l}\text { The selection of dominant } \\
\text { color }\end{array}$ & The selection of color \\
\hline $\begin{array}{l}\text { The absence of } \\
\text { school/place for study }\end{array}$ & $\begin{array}{l}\text { The location of study } \\
\text { room }\end{array}$ \\
\hline $\begin{array}{l}\text { A group of people } \\
\text { playing card }\end{array}$ & $\begin{array}{l}\text { The drunkard urinated in } \\
\text { the semi ground } \\
\text { apartment's window }\end{array}$ \\
\hline A ruined building & $\begin{array}{l}\text { A trapped man in the } \\
\text { ground }\end{array}$ \\
\hline
\end{tabular}

The connotative code in ALNI can be identified in its settings, characters, plot, and dialogues. The selection of characters and their point of view codes the social class, knowledge, and belief connotatively. The characters' language, costumes, environment guides the audience to 
identify their position in the narration. For example, the position of Haji Sabirin to Haji Makbul, the position of Pipit, Muluk, and Syamsuddin as University Alumnae, and the pickpockets. All the attributes speak about their position in the plot connotatively as they represent symbols for society as a whole.

Furthermore, the selection of dominant dark and white colors in the setting is the code of the nuance of the theme. All represent hopeless lowerclass people who live in a densely populated area in the capital city Jakarta. The appearance of all these characters who are from the same location but have a different view on education allows the narrative to express the current concern regarding an educational and political problem in lower-class Indonesian society. The hope for those educated people is either to elevate the family's class status or country's prosperity seems to fade away, represented in gloomy color. Surprisingly, amidst the hectic dialogue on education, no school or study room appears in the scene. This signifies the absence of education in the lower class.

Similarly, in Parasite, the location and the form of the house connotatively unveil the family's social location. The location semi-basement apartment and the drunkard's urination connotatively represent the social location of Kim's family. Meanwhile, the location of Mr. Park's house in the upper hill, the steps passed by the Kim to reach the upper hill house, and the location of the study room in the upper hill house connotatively illustrate the position of education in the belief and culture of the Park family. There is no education in the lower ground, but there is education in the upper hill. Therefore, the Park accepts Ki Woo's offer for the belief that only rich people can attain the best education.

As Parasite is juxtaposing the rich and poor families, the color of the different houses is also different. The poor people's houses have darker color while the rich ones are full of natural color. The rich have the best natural resources, while the poor have the natural disaster. The upper hill houses offer living like a dream, while the semi-basement apartment traps the men in the lowest ground, the lowest level of life.

The position of education shows that Korea and Indonesia have different perspectives. In Korea, education is unquestionably crucial, meanwhile in Indonesia, the function of education still debatable, this can be seen in the absence of a place for study like a school or study room. However, the inclusion of the mosque and the absence study room in ALNI unconsciously shows that a strong vertical relation in terms of human-god relation. Regarding this relation, ALNI unveils the character's doubt to higher education in the expression that it is education that produces smart thieves, and teaches people to rob the nations' property. Similarly,
Parasite also emphasizes that an unskillful teacher makes the worst students and brings disaster to a family and/or a nation.

\begin{abstract}
Symbolic code
The focus of this code is to identify opposing textual elements which repeatedly occur in the plot. A simple binary polarity system can be identified as a symbolic code. As can be seen in Table 4, there is a number of opposing events identified in these satiric movies.
\end{abstract}

\section{Table 4}

Symbolic Code

\begin{tabular}{ll}
\hline $\boldsymbol{A L N I}$ & Parasite \\
\hline $\begin{array}{l}\text { The debate concerning } \\
\text { education on } \\
\text { alumnae's skills }\end{array}$ & $\begin{array}{c}\text { False diploma/skill and } \\
\text { experience }\end{array}$ \\
$\begin{array}{c}\text { Critical pickpocket VS } \\
\text { Hopeless university } \\
\text { Alumnae }\end{array}$ & $\begin{array}{c}\text { Smart poor thieves' } \\
\text { daughter vs. busy } \\
\text { Corruption vs pickpocket }\end{array}$ \\
$\begin{array}{l}\text { ambitious rich people's } \\
\text { daughter }\end{array}$ \\
& $\begin{array}{c}\text { Lower class Vs. Higher } \\
\text { class's daughter }\end{array}$ \\
\hline
\end{tabular}

ALNI portrays a number of repeated opposing scenes such as the divergent point of view between Pak Makbul dan Haji Sabirin. Throughout the movie, this scene frequently occurs whenever the two characters are focused on by the camera. This repeated conversation helps readers to focus on the theme namely higher education. Another repeated opposing scene is the juxtaposing of hopeless but educated unemployed people such as Syamsul and Pipit to the busy and illiterate pickpockets. The educated people spend their day sitting waiting for fortune either from winning gambling or from answering quizzes correctly. On the contrary, the pickpockets who do not have any formal education seize the street and other public places in the city from the early morning until late at night chasing their fortune. Furthermore, the repeated opposing scene can also be identified in the narration of the destruction made by the corruptors compared to the education initiated by the pickpocket.

Another antithetical element is the irony contained in the dialogue between Comet and Muluk regarding the goal of people pursuing education. Muluk, who needs to be financially independent, uses his knowledge and intelligence to manage the pickpockets' income, from which he has his share of about ten percent. This paradoxical unit gives birth to another paradoxical argument regarding education and corruption. Here the film shows the ambiguous meaning of education gained from university.

The symbolic code shown in Parasite occurs in the repeated lies made by the Kims. The first lie is Mr. Kim's cheating at folding pizza boxes. Another lie is when Ki Jung insists on full payment 
for the pizza box by threatening that she is the friend of the pizza owner. Ki Woo also lies regarding his and his sister's diploma. Ki Jung lies about her father and mother's skills so that they can work at Mr. Park's house. These lies show that a poor family is smart people, and the absence of education and opportunity leads them to be smart thieves.

Another opposing code the repeatedly occurs is the position of the daughters of both the poor and rich family. Mrs. Park forces additional education at home upon her daughter so that she can be admitted to the best university. She has a very important position, which is to maintain the family's social location. Similar to Mr. Park's family, Mr. Kim's daughter also poses a strong position in the family. Throughout the movie, the Park's daughter plays a crucial role in the family's decision and leads the family's orientation. She is very good at fabricating the diploma and acting as the daughter of a rich family who graduated from an American university. The daughters of both families seem to take a certain important position. These codes unconsciously become the significance of women's position in the social changes.

\section{Cultural code}

Cultural code compiles any unit in this narrative that denotes a science or a body of knowledge such as physical, physiological, medical, psychological, literary, and historical properties of characters in the story to identify a common knowledge. As a reference to a science or scientific institution, usually, this code indicates the type of knowledge and it tries to construct a culture that takes place at a particular time trying to be expressed. This code, in Table 5, is also known as the voice of science.

Table 5

Cultural Code

\begin{tabular}{ll}
\hline ALNI & Parasite \\
\hline Mosque and security post & $\begin{array}{l}\text { Scholar Stone (Suseok) } \\
\text { Aslamic terms }\end{array}$ \\
& $\begin{array}{l}\text { American Culture: Burger } \\
\text { and native }\end{array}$ \\
\hline
\end{tabular}

Cultural code can be seen in the position of the mosque and the security post in the middle of the kampong. It shows the vertical and horizontal relation of the lower-class people. Mosques are a place where people, such as Pak Makbul, pray and hope for a better life. The security post is a place where hopeless people, such as Samsul, escape from the reality of being jobless. The selection of these two places shows the importance of vertical and horizontal relations of these communities. Islamic knowledge as a cultural code can be seen in the older people's conversation when they find out that the children earn money by pickpocketing. They consider it haram because they steal the money. The two later beg to be forgiven by God in the mosque.
In Parasite, cultural code appears in a scholar stone or suseok, a gift to Kim Ki Woo from Min Hyuk, his friend. This stone codes a cultural belief in Korea which was popular during the 14-19 century. A scholar stone is popular among businessmen who do not come from a great academic background and old family money, but they make a lot of money. The stone is considered to be an easy step to be rich and it is popular among newly wealthy people (Chernick, 2020). Therefore, the selection of scholar stone in Parasite is the perfect code to regulate the flow of the plot perfectly. Its inclusion also underlines the criticism of the movie toward the intention that people attain education for money.

Another cultural code that occurs is American culture. This code is present in the Park's house but absent in the Kim's house. When $\mathrm{Ki}$ woo and $\mathrm{Ki}$ Jung are in the Park's house they transform into Kevin and Jessica. English names, American culture, and western food signify their social location.

From analyzing the codes that structured the narrative, it can be seen that almost all codes structured in the two films focus on education. Therefore, the film intends to show the facts of how lower-class people struggle with the current changes in education. The below discussion elaborates why education becomes the focus of this satiric movie and why satire is considered a useful tool to inspire.

\section{DISCUSSION}

As can be seen from the comparative structural narrative analysis, these two films use satire to show their intention and to inspire their audience. There are several intentions that these films show regarding higher education in both countries.

Firstly, the two films introduce the common beliefs held by most people that higher education may help to solve the problem of poverty in the beginning. The South Korean and Indonesian films emphasize this principle by showing that poverty and ignorance allow people to commit crimes. The pickpockets steal money, and the Kim family cheats on the lower-paying job. Then, the films challenge this belief by presenting the struggle of the pickpockets to attain education and the Kim's to fake their diploma in order to have an opportunity to make a bigger income. In other words, the desire to make money leads the characters of the two films to attain education. Education has become an exchange commodity good. This part is highlighted in the conversation between Samsul and Pipit, who help Muluk to teach the pickpockets. After this conversation, they see a pickpocket coming out of the mosque after praying. They notice that he is wearing new sandals, and the pickpocket admits that he stole them from the mosque. 
Samsul understands that education is not merely a way to elevate people, social class, and material capital. Education is neither like Haji Sabirin's belief nor Pak Makbul's hope. However, it has a more significant function, namely morality. Without it, higher education will create more corruptors. These units also show the message of the movie when the pickpocket's big boss order all the pickpockets to attain a better education. He believes that it will change them into better people, to not merely grow up and then die, but education makes them value themselves and other people.

A similar tone is also implied in Parasite. Even though the Kims have successfully transformed their looks into a higher level, their smell stays on their body. The pickpockets and the Kims metaphorically represent college students buying and selling knowledge to earn money. It shows that what students should learn at school and value in education is relative to their prospects for future income as the pickpockets. Besides, the purpose of teaching is not intended to develop better individuals but to earn an income much like Ki Yoo and Ki Jung. The pickpockets and Ki Yoo represent the manifestations of neoliberalism in education.

Neoliberalism is a political project practiced by the capitalist class for profit by using the political process's influence to privatize or direct state institutions and control favorable powers to their interest. The illustration of the films is a parallel to what is shown in the research on neoliberalism in American higher education (Giroux \& Giroux, 2004), neoliberalism in South Korean education (Byean, 2015; Lim, 2006), and in Indonesia (Rachman, 2017; Wahyudi, 2015).

Both films criticize the impact of neoliberalism through paradox and satiric humor. Criticism in humor is always associated with criticism in morality, as shown in ALNI and Parasite (Dadlez, 2011 , p. 1). Parasite satirically highlights uneducated and dishonest individuals' intention to be involved in teaching and educating people. Similarly, ALNI underlines the intention of the pickpockets in attaining education. As a result, Parasite shows that this kind of intention, despite making a better nation metaphorically depicted as a modern home in the upper hill, ruins the already established system.

Similarly, ALNI shows the product of education in the characters of Muluk, Syamsul, Pipit, and the pickpocket who comes out of the mosque. Muluk, Pipit, and Syamsul are trapped in their sole ability of their major, managing others and teaching others, but they cannot inspire themselves. Nonetheless, the pickpocket only thinks about enriching himself. As a humorous film, it is not surprising that most people view the film as social critics, such as research by Sudarso et al. (2015) and Anwar (2019).
Furthermore, the significance of money and honesty is highlighted in ALNI and Parasite. This film metaphorically juxtaposes the scene of Muluk and the pickpocket earning money to the scene of the conversation of educated people dishonestly earning money but respected by society and the government. Similarly, Parasite clearly describes the dishonesty of the Kims in earning money. Both films underline the moral belief that honesty brings about respect and pride. This theme is satirically lamented in both films. By showing this message, as a social critic, the films do not only intend to entertain the audience but also to inspire the audience into action.

In contrast to a romantic film that gains attention by moving and touching their audience's heart, these satiric films attract their audience by making fun of their object. As satire films, they are part of comedy that is not considered politically powerful to change the country's social system. Satire is not commonly regarded to be a form of critical intervention as other public intellectual works such as political speeches or editorials, incisive critical commentaries, social theories, or even tragedies. Comedy does not consist of serious tones aimed at agitating its audience to care about unjust, unfair, and unreasonable social practices but it helps people to be happy and escape from their everyday problems (Cawelty, 1976).

As a form of critical intervention, these satiric movies are potentially involved in educating their audience. The involvement of film in educating people is due to the failure of formal education to insert moral education in its curriculum. McClennen (2011, p. 3) and Giroux (2006, p. 318) termed this involvement as public pedagogy. They believe that the use of satire is intended to attract people's attention to the problem that the audience probably is not aware of. These satirical movies pose as part of public pedagogy. They insert morality, empathy, and social awareness to answer the changes undergoing in higher education that focuses on equipping students with vocational sciencetechnological training rather than moral and mental education experience in both countries. As a result, public education occurs more often outside the classroom. Indeed, the two films attract people's attention to laugh at their country's education, which is their own problem. They also give pleasure in amusing the audience with their foolishness

However, Humor is not an aesthetic experience that moves people into action. According to Gordon (2012, p. 120), aesthetic experience has a range of emotions that the art is designed to arouse greatly, from sadness to joy and anger to serenity. Moreover, humor is assessed not based on beauty but rather by how funny it is, and it is a fundamentally social experience. The aesthetic experience generally involves a much deeper change than when people laugh. It is a social phenomenon that amuses people 
and makes them laugh. The aesthetic experience takes a more considerable beauty personal work that moves people into very personal experience. However, by observing a satiric show on American television, McClennen (2011, p. 181) states that satire is regarded as a form of art that potentially provokes political apathy and narcissistic diversion. It is explained that humor has offered ways to be productively engaged in contemporary politics. It means that if aesthetic beauty is intended to entertain the audience generally, humor is directed to moral politics. The audience of the films laughs when watching the films. What the viewers do after they have done watching is never understood. Nevertheless, the work of art still opens up many possibilities. The two satirical films possibly work slower than those of higher works of art such as tragedy, but they enrich people's awareness.

\section{CONCLUSION}

This study has addressed the questions regarding the implicit meaning of the two movies' intention and inspiration through the use of structural semiotic approach. The analysis results imply that although economic progress and infrastructure are different, the two movies actually narrate similar problems in education. Both believe that education elevates people's class, but at the same time, the two films show their concern when education is about forming students to focus on their individual earning in the future. The two films show that the involvement of dishonest people in the process of education damages the result. The Kim family's dishonesty is highlighted, so are those of the pickpockets', Muluk's, and the corruptors.' With this, the films implicitly show that the intention of becoming rich and living lavishly may allow people to become dishonest.

Through comparing the structure of narration from the two films, it can be seen that the impact of the instilment of neoliberalism in education in every country is almost the same. It gives moral and ethical consequences to the lower-class and higher class, as shown at the end of the films. The two films use the form of satire to address this crucial problem. Satire is used to invite the audience to laugh and amuse in their own foolishness so that they are aware of their mistake and stupidity. Satire is used to inspire people to make the change and to stray from their fault. These films have alternatively become a public pedagogy through the satiric form that provides moral knowledge, which is absent at formal schools where science and technology seem more attractive.

\section{REFERENCES}

Abelmann, N., Park, S. J., \& Kim, H. (2009).

College rank and neo-liberal subjectivity in South Korea: The burden of self-development.
Inter-Asia Cultural Studies, 10(2), 229-247. https://doi.org/10.1080/14649370902823371

Allen, G. (2003). Roland Barthes. London: Routledge.

Amin, S. (2016). Landadi Manusial Dadi Manca: Struktur dan agensi dalam mobilitas sosial vertikal orang Makeang di Maluku Utara. Gadjah Mada University.

Anwar, F. (2019). Kritik sosial dalam naskah drama Alangkah Lucunya Negeri Ini karya Deddy Mizwar. Jurnal Bahasa dan Sastra, 4(1), 105121. https://doi.org/10.31219/osf.io/wx7td

Barthes, R. (1977). Image-music-text. Fontana Press.

Barthes, R. (2002). S/Z. Blackwell Publishing.

Bradshaw, P. (2020). Parasite review - searing satire of a family at war with the rich $\mid$ Parasite. The Guardian. Retrieved from https://www.theguardian.com/film/2020/feb/0 7/parasite-review-bong-joon-ho-south-koreansatire

Byean, H. (2015). English, tracking, and neoliberalization of education in South Korea. TESOL Quarterly, 49(4), 867-882. https://doi.org/10.1002/tesq.257

Cawelty, J. G. (1976). Adventures, mystery, and romance. The University of Chicago.

Chandler, D. (2007). Semiotics the basic ( $2^{\text {nd }}$ ed.). Routledge.

Chernick, K. (2020). A highly collectible rock plays a key role in the oscar-nominated film "Parasite." Here's the actual meaning behind it. Artnet. Retrieved April 18, 2021, from https://news.artnet.com/art-world/guidesuseok-stone-parasite-1768059

Dadlez, E. M. (2011). Truly funny: Humor, irony, and satire as moral criticism. Journal of Aesthetic Education, 45(1), 1-17. https://doi.org/10.1353/jae.2011.0003

Faruk. (2018). Nasionalisme puitis. Pustaka Pelajar. Giroux, H. A. (2006). America on the edge: Henry Giroux on politics, culture, and education. Palgrave Macmillan.

Giroux, H. A., \& Giroux, S. S. (2004). Take back higher education race, youth and the cricis of democracy in the post-civil rights era. Palgrave Macmillan.

Gordon, M. (2012). Exploring the relationship between humor and aesthetic experience. Journal of Aesthetic Education, 46(1), 110 121. https://doi.org/10.5406/jaesteduc.46.1.0110

Hasanah, S., Fikri, H., \& Gusnetti. (2017). Nilainilai pendidikan karakter dan konflik tokoh utama dalam film Alangkah Lucunya Negeri Ini. Jurnal ILmu Komunikasi Mediakom, 1(1).

Johansen, J. D., \& Larsen, E. S. (2004). Signs in use: An introduction to semiotics. Routledge.

Kompas. (2019). KPK: Para koruptor paling banyak berpendidikan tinggi. Kompas. 
Retrieved December 15, 2020, from https://nasional.kompas.com/read/2019/05/15/ 13530321/kpk-para-koruptor-paling-banyakberpendidikan-tinggi?page $=$ all

Lim, H.-C. (2006). Between neoliberalism and democracy: The transformation of the developmental state in South Korea. Development and Society, 35(1), 1-28.

McClennen, S. A. (2011). Education, politics, and public life. Palgrave Macmillan.

McClennen, S. A., \& Maisel, R. M. (2014). Is satire saving our nation?: Mockery and American politics. Palgrave Macmillan.

McQuillan, M. (2002). The narrative reader. Routledge.

Media Indonesia. (2019). KPK: Mayoritas koruptor berpendidikan tinggi. Media Indoneisa. Retrieved December 15, 2020, from https://mediaindonesia.com/politik-danhukum/235855/kpk-mayoritas-koruptorberpendidikan-tinggi

Okezone. (2019). KPK: Berdasarkan data, koruptor paling dominan bergelar master. Okezone. Retrieved December 15, 2020, from https://nasional.okezone.com/read/2019/05/15 /337/2056078/kpk-berdasarkan-data-koruptorpaling-dominan-bergelar-master

Rachman, A. (2017). Neoliberalism and inclusivity in Indonesian higher education. University College London.

Republika Online. (2020). KPK catat 64 persen koruptor adalah alumni perguruan tinggi. Republika Online. Retrieved December 15, 2020, from https://republika.co.id/berita/qhipo6328/kpkcatat-64-persen-koruptor-adalah-alumni- perguruan-tinggi

Sims, D. (2019). How Bong Joon Ho invented the weird world of Parasite. The Atlantic.

Retrieved from https://www.theatlantic.com/entertainment/arc hive/2019/10/bong-joon-ho-parasiteinterview/600007/

Sudarso, A. D., Senduk, J., \& Rembang, M. (2015). Analisis semiotika film "Alangkah Lucunya Negeri Ini." Acta Diurna, IV(1).

Susanti, A., \& Asyari, I. (2017). Nilai pendidikan dalam film Alangkah Lucunya Negeri Ini. Mediakom, 1(1). https://doi.org/10.32528/mdk.v1i1.678

Sutanto, N. (2016). Neoliberalism within psychology higher education in Indonesia. Anima, Indonesian Psychological Journal, 32(1), 1-11.

Wahyudi, I. (2015). Komersialsasi pendidikan tinggi di Indonesia. Tw'azun, 8(1), 49-70.

Wartakota. (2019). KPK Sebut 86 persen koruptor berpendidikan tinggi, ternyata di sini lokasi berpotensi rawan koruptor. Wartakota. Retrieved December 15, 2020, from https://wartakota.tribunnews.com/2019/05/15/ kpk-sebut-86-persen-koruptor-berpendidikantinggi-ternyata-di-sini-lokasi-berpotensirawan-korupsi

\section{Data Source}

Alangkah Lucunya (Negeri Ini). (2010). Citra Sinema

Parasite [Gisaengchung]. (2019). Barunson E\&A Corp 